\title{
Fuel Exemptions, Revenue Recycling, Equity and Efficiency: Evaluating Post-Kyoto Policies for Switzerland
}

\author{
JAN IMHOF ${ }^{\mathrm{a}}$
}

JEL-Classification: D31, D58, H23, Q48, Q52, Q58

Keywords: Carbon Tax, Computable General Equilibrium, Double Dividend, Tax Exemptions, Climate Cent, Distributional Consequences

\section{Introduction}

The Swiss parliament is in the process of revising its $\mathrm{CO}_{2}$ law as its reduction targets are running out in accordance with the first commitment period of the Kyoto Protocol. It is very likely that the parliament will extend measures already in place. Those measures consist of a $\mathrm{CO}_{2}$ tax on stationary fuels of $36 \mathrm{CHF}$ per ton of $\mathrm{CO}_{2}$ and the Climate Cent ${ }^{1}$ for transportation fuels. In addition, the parliament is likely to impose a domestic reduction target of 20\% below 1990 levels by 2020, in line with current EU proposals. Taking into consideration the official $\mathrm{CO}_{2}$ balance (Federal OfFice for the Environment, 2011) it seems likely that the current policy measures are not strict enough to fulfill this ambitious future emission reduction target. Additionally, the Climate Cent scheme - equivalent to an exemption of transportation fuels from the $\mathrm{CO}_{2} \operatorname{tax}-$ is controversial, since first, transportation fuels have seen continually increasing use under the policy, and second, a cost-effective carbon policy guaranteeing the equalization of marginal abatement costs is absent. ${ }^{2}$

a Centre for Energy Policy and Economics, ETH Zurich, Zürichbergstrasse 18, CH-8034 Zurich, Switzerland. Email: imhofj@ethz.ch. The author wishes to thank Thomas Rutherford, two anonymous reviewers and participants of the $67^{\text {th }}$ Congress of the IIPF, the 2011 international conference of the IAEE and the YSEM 2011 in Bern for helpful comments and suggestions. All remaining errors are the author's responsibility.

1 The Climate Cent foundation is financed by a charge of 1.5 Swiss Cents levied on every liter of gasoline and diesel sold at the pump. This corresponds to roughly $6 \mathrm{CHF}$ per ton of $\mathrm{CO}_{2}$.

2 See Boehringer (2002) for a textbook discussion of the importance of equalizing marginal abatement costs. 
Efficiency and equity issues associated with green taxes are discussed broadly in the literature. One branch of literature focuses specifically on the economic efficiency of green tax reforms. Papers discuss either the double dividend, achievable by reducing distorting pre-existing taxes through revenue recycling (e.g. BovenBerg and De Mooij, 1994; Goulder, 1995; and Wissema and Dellink, 2007), or the efficiency losses or gains due to tax exemptions (e.g. BöHringer and Rutherford, 1997; Paltsev et al., 2005; or Abrell, 2010). While Böhringer and Rutherford (1997) show that sectoral tax exemptions may hurt economic efficiency considerably since marginal abatement cost are not equalized, ABrelL (2010) finds that tax exemptions for transportation fuels increase welfare. However, Paltsev et al. (2005) point out that pre-existing fuel taxes are important, as tax exemptions for transportation fuels may "correct pre-existing distortions and reduce the cost" in Europe, while a uniform taxation in the US can reach a given reduction target at least cost. The explanation for their finding is that a pre-existing petroleum tax may act as a pre-existing $\mathrm{CO}_{2}$ tax on transportation fuels. Equalizing marginal abatement costs over fuels imposes different $\mathrm{CO}_{2}$ tax rates such that pre-existing fuel taxes are equaled out. However, this only holds if it is assumed that the pre-existing fuel tax is useless and does not internalize any external effect. Otherwise, if the pre-existing fuel tax is a perfect Pigouvian tax this argument does not hold and the optimal $\mathrm{CO}_{2}$ taxes should be set at an equal rate regardless of other fuel taxes.

The second branch of literature is concerned with the distributional effects of green tax reforms and with tax incidence. While generally carbon taxes have been shown to be regressive (Poterba, 1991; Jorgenson, SLesnik, and WilCoXen, 1992; OECD, 1995; Scott and Eakins, 2004; or Wier et al., 2005), ${ }^{3}$ Metcalf $(1999,2007)$ points out that, depending on the mode of revenue recycling, effects on the income side can lead to almost any desired distributional outcome. Graigner and Kolstad (2009) show that revenue recycling can offset disproportional effects on households. This dominating effect of revenue recycling is not surprising, since fuel expenditures are usually only a minor budgetary item. However, the question why undesired distributional outcomes should be approached directly via the green tax reform remains. AtKinson and STIGLitz (1976) show that income taxation should be employed to redistribute income.

3 In developed countries poorer households tend to spend a bigger share of their disposable income on energy. There is strong evidence that this does not hold for developing countries (Boyce, Brenner, and Riddle, 2005; Van Heerden et al., 2006; Yusuf and Resosudarmo, 2007; Corong, 2008). 
JACOBS (2011) explicitly shows that in the optimal environmental tax reform distributional issues should be addressed with non-linear income taxes. In Switzerland, however, where direct federal tax rates are rather low, the distributional outcome has to be addressed directly in a green tax reform, since cantonal direct tax rates are not accessible.

Finally there is a branch of studies conducted for Switzerland. MüLLER and van Nieuw koop (2009) and Sceia, Thalmann, and Vielle (2010) examine the economic effects of the revised $\mathrm{CO}_{2}$ law. However, they base their scenarios on the original proposals from the Federal Council which have changed significantly since the debate in the federal parliament.

In light of the revision of the $\mathrm{CO}_{2}$ law this paper aims to examine different potential Post-Kyoto policies for Switzerland. First, the paper poses the question of how high carbon tax rates need to be in order to reduce domestic $\mathrm{CO}_{2}$ emissions by $20 \%$. Second, the paper estimates the economy-wide cost of a reduction of $\mathrm{CO}_{2}$ emissions by $20 \%$ below 1990 levels and compares different revenue-neutral policy proposals regarding revenue recycling and exemptions for transportation fuels. Third, the paper examines the distributional outcomes of the different tax regimes.

This will be accomplished using the static CEPE model. ${ }^{4} \mathrm{CEPE}$ is a static computable general equilibrium model of the Swiss economy, suitable for climate and energy policy evaluation. The model portrays Switzerland as a small open economy incorporating 14 household groups, 42 producing sectors and 51 goods of which 9 are energy goods. This paper provides estimates of the economic impact of the $\mathrm{CO}_{2}$ law revision based on recent developments of the debate in parliament. The paper also reexamines the role of exemptions for equity, something which has not been addressed in other CGE studies.

The remainder of the paper is organized as follows. Section 2 describes the static CEPE model. Section 3 outlines the scenarios and discusses the results. Section 4 examines the stability of the results regarding the parameters of the model. Finally Section 5 summarizes the results.

4 CEPE stands for Climate and Energy Policy Evaluation Model of the Swiss economy. I developed a dynamic version of this model for a recent exercise of Stanford's Energy Modeling Forum. See Iмноғ (2011). 


\section{The CEPE Model}

CEPE is a static computable general equilibrium (CGE) model that represents Switzerland as a small open economy. The static model captures the main structure of the Swiss economy and is calibrated to the input-output table for 2005. The model contains 42 sectors. ${ }^{5}$ The technologies in use are constant returns to scale, such that the sectors exhibit zero profits. On the demand side the model incorporates 14 household groups representing retired and working households in different income quantiles. ${ }^{6}$ Households maximize utility subject to their budget constraints. Different consumption goods are aggregated with fixed expenditure shares. The consumer then trades off leisure with consumption following the approach favored by BALLARD (1999). Households provide labor and capital and receive lump-sum transfers. The government buys a fixed basket of goods in all scenarios. It pays for this by collecting value-added taxes, excise taxes, and direct taxes. The government budget is balanced by transfers to the households. If there is additional revenue from environmental taxes, the government recycles the additional revenue in different schemes specified in the scenarios. Tax reforms are always considered to be revenue-neutral.

\subsection{Data}

CEPE is calibrated to the Swiss 2005 Input-Output table. This table was originally developed by the ETH in collaboration with Ecoplan Bern (NATHANi and Wickart, 2006; Nathani, Wickart, and van Nieuw koop, 2008). A second important data input are the elasticities of substitution. In the 2005 IO table energy goods are rather rough aggregates. CEPE exploits a database containing data on sectoral energy goods usage in physical units and sectoral energy prices to disaggregate the energy goods further. This allows the representation of sectoral energy use in the model and, thus, sectoral carbon emissions from fossil fuel combustion. Finally I apply the income and expenditure survey of 2001 to disaggregate final demand. CEPE incorporates 14 different household groups

5 A list of all sectors in the model can be found in Appendix D.

6 The households are denoted by EH1 to EH10 from the poorest to the richest income decile of employed households. The retired households are denoted by RH1 to RH4 from the poorest to the richest income quartile.

7 Those transfers represent social security and other payments from the government to households. When the carbon tax is redistributed lump-sum the payments are added to those transfers. 
in the model. The households are classified into 10 income deciles of working households and 4 income quartiles of retired households, as shown in Table 9 in Appendix B.

\subsection{Tax System}

Direct taxes at the federal level are not very important. Total revenue from income taxes, property taxes, and taxes on profits accounted for only 12.2 billion CHF in 2005. On the other hand, direct taxes are responsible for the bulk of community and cantonal tax revenues and account for around 73.3 billion CHF. Therefore I add cantonal and communal direct taxes to the federal income and redistribute the additional fictive income of the federal government via transfers to the households. The direct income tax is then levied on capital and labor earnings, resulting in ad-valorem tax rates of 23.8 and $23.3 \%$ respectively. These rates are a much closer representation of the true pre-existing tax distortions than if I had only considered federal charges.

In 2005 , a value-added tax with a maximum rate of $7.6 \%$ gathered 18.2 billion $\mathrm{CHF}$ in revenue. ${ }^{8}$ Sectoral value-added tax payments are reported in the input-output table, and I use those to compute average sectoral value-added advalorem tax rates on capital and labor inputs such that sectoral tax revenues fit the data. The federal government levies taxes on tobacco, alcohol, and cars and charges import tariffs. A petroleum tax is charged at a rate of 73.1 Swiss cents per liter of gasoline and 75.9 cents per liter of diesel. The tax on heating oil is only 0.3 cents per liter and is thus neglected in the model. Since approximately two third of the petroleum tax revenue is used for road maintenance and building, I do not consider this part of the tax in the model as its benefits (through an increased public good) are not accounted for in the model. ${ }^{9}$ This is in line with PAltsev et al. (2005), who argue that the petroleum tax in the US can be ignored as it is used entirely for transportation purposes. ${ }^{10}$ This results in a distorting petroleum tax of 21.6 cents per liter of gasoline and 24.4 cents per liter of

8 While most goods were taxed with $7.6 \%$, there were tax rates of $3.6 \%$ for hotels and $2.4 \%$ for certain other goods.

930 cents per liter of gasoline and diesel (Mineralölsteuerzuschlag) and half of the ordinary petroleum tax (Mineralölsteuer) are used for financing transportation.

10 To ignore a share of the pre-existing tax is of course awkward since the associated excess burden will not be considered in the model. On the other hand, including the distorting share of the tax without modeling the externalities would distort the model's results even more. Further research in this point seems to be worthwhile. 
diesel, which produced general federal revenue of 1.5 billion CHF in 2005. The extent to which the pre-existing fuel tax is not internalizing any external effect, and, therefore, has to be deducted from a $\mathrm{CO}_{2} \operatorname{tax}$ is debatable and is subject to further research ${ }^{11}$. If the tax rates are computed per ton of carbon this results in pre-existing $\mathrm{CO}_{2}$ taxes of 92 and $95 \mathrm{CHF}$ per ton of $\mathrm{CO}_{2}$, respectively.

\subsection{Energy Goods and Production}

CEPE covers 9 energy goods: fuel oil, natural gas, coal, electricity, gasoline, diesel, kerosene and uranium. Switzerland is not endowed with any primary energy resources and has to import crude oil, coal, natural gas, crude oil and uranium. While about half of Switzerland's demand for refined oil products is met by imports, the other half is produced from crude in the oil processing sector. The model includes an electricity sector which produces electricity using capital, labor and uranium as its major inputs. Other intermediates and small amounts of other energy inputs enter the production function in the same way as in other sectors.

The nested CES production function, common to all sectors (with the exemption of the transport sector), and the associated elasticities of substitution are illustrated in Figure 1. On the top nest less important energy sources such as $\mathrm{coal}^{12}$ and kerosene ${ }^{13}$ are substituted with a value-added composite, intermediate goods and an energy aggregate with an elasticity of substitution of 0.5 . The energy aggregate is produced in a Cobb-Douglas nest from electricity and fossil fuels, which combine fuel oil and natural gas inputs, substitutable with a constant elasticity of 2 .

Gasoline and diesel enter production via the transportation sector. The fuels are aggregated with a Leontief technology and the aggregate trades off with other inputs with an elasticity of 0.5 . The transport good is then bought by households and, to a lesser extent, by other sectors.

11 I could as well assume that the remainder of the tax internalizes other externalities as noise, congestion or local air pollution, and, thus, is justified as well. However, the important point I want to make is, that the unjustified share of the tax, however large it may be, has to be deducted from the new $\mathrm{CO}_{2}$ tax.

12 Coal plays a minor role in the Swiss economy, accounting for less than one percent of total primary energy supply.

13 Kerosene is only used in the air transportation sector. 
Figure 1: Production Function Nesting Applied to All Sectors

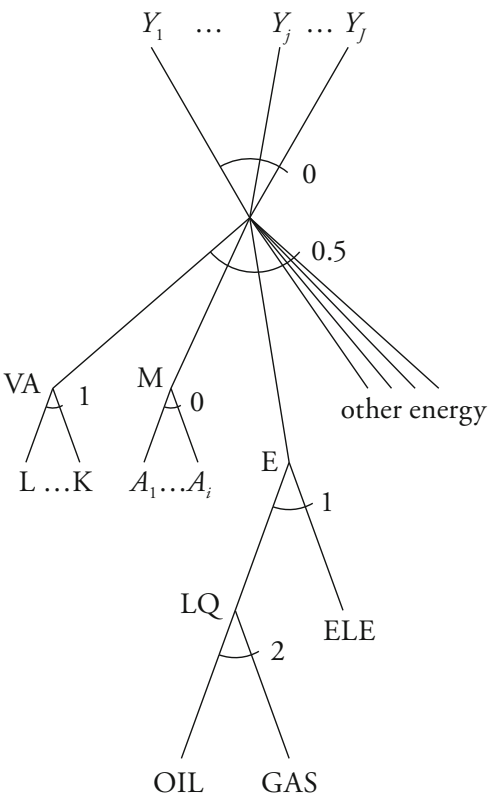

\section{Scenario and Results}

\subsection{Policy Scenarios}

The model's BAU scenario is calibrated to 2005 data and I do comparative static analysis using policies that achieve a $20 \%$ reduction of $\mathrm{CO}_{2}$ emissions below 1990 levels in 2005. I consider three tax policies. The first scenario is a uniform tax on carbon dioxide emissions from fossil fuel combustion ("Uniform"). The tax applies to all stationary and transportation fuels sold in Switzerland. No border measures apply in any setting. The second policy scenario ("Optimal tax") is a carbon tax with different rates for emissions produced from different sources. The carbon tax on transportation fuels is 90 CHF less than that for stationary fuels in order to correct for the distorting share of the petroleum tax. ${ }^{14}$ The third

14 The same effects could be obtained by implementing a uniform $\mathrm{CO}_{2}$ tax while the distorting share of the petroleum tax would be abandoned. 
policy scenario ("Exempt") is a carbon tax on stationary fuels only. Note, however, that the initial petroleum excise tax remains in place.

I generate results for each of these three tax scenarios using four different revenue recycling schemes. The government is assumed to keep tax changes revenueneutral by recycling carbon tax income either lump-sum or through a uniform reduction in value-added taxes, labor, or capital taxes.

\subsection{Marginal Costs of Abatement and Carbon Emissions}

Table 1 shows the carbon tax rates, which range between 289 and $696 \mathrm{CHF}$ per ton of $\mathrm{CO}_{2}$ for a $20 \%$ reduction. Note that only the ordinary tax rates for stationary fuels are reported. Transportation fuels are taxed less than the reported rate in the "optimal tax" and in the "exempt" counterfactuals.

Table 1: Marginal Abatement Cost in $\mathrm{CHF} / \mathrm{t} \mathrm{CO}_{2}$

\begin{tabular}{lccc}
\hline & Uniform & Optimal tax & Exempt \\
\hline lump-sum & 291 & 352 & 646 \\
vat & 306 & 369 & 674 \\
capital & 289 & 350 & 637 \\
labor & 303 & 371 & 696 \\
\hline
\end{tabular}

The influence of the recycling schemes regarding tax rates is slight. Uniform tax rates vary between 289 and $306 \mathrm{CHF} /$ ton $\mathrm{CO}_{2}$, while tax rates on stationary fuels only range between 637 and $696 \mathrm{CHF}$. It is not surprising that marginal costs are around doubled in the exemption cases, since the burden of $\mathrm{CO}_{2}$ reduction is shifted entirely to stationary fuels. As the tax base declines, tax rates have to increase in order to have the same absolute effect on $\mathrm{CO}_{2}$ emissions. Altering the system of rebatement has no direct effect on emission levels, making only a slight change to tax rates necessary. Their influence is mostly seen in the effects on efficiency. The reduction of very distortionary taxes may increase economic activity and, by propelling energy demand, make higher carbon prices necessary to achieve a given reduction target. Carbon prices reported may seem high but are comparable with those obtained in other studies. Müller and van Nieuw koop (2009) report $\mathrm{CO}_{2}$ tax rates as high as $325 \mathrm{CHF} / \mathrm{t} \mathrm{CO}$. Sceia, Thalmann, and VIELLE (2010) obtain prices up to $468 \mathrm{CHF}$ per ton of $\mathrm{CO}_{2}$ equivalent. However, 
their scenarios differ from mine with respect to two things. First, they apply less strict abatement targets since the first draft of the revised $\mathrm{CO}_{2}$ law did not required to achieve all emission reductions domestically. And second, they use more optimistic assumptions on technological change with respect to carbon intensity. While they assume that $\mathrm{CO}_{2}$ emissions decrease until 2020 under a BAU scenario without any active policy measures in place, I implicitly assume that carbon intensity of production does not improve. Instead, I apply long-term elasticities of substitution to account for increased technological knowledge in 2020 .

Table 2: $\mathrm{CO}_{2}$ Emission Levels in Million Tons and $\mathrm{CO}_{2}$ Reduction in \% w.r.t. 1990 under a Lump-Sum Recycling Scheme

\begin{tabular}{lccccc}
\hline & 1990 & 2005 & Uniform & Optimal tax & Exempt \\
\hline Transportation fuels & 15.5 & $\begin{array}{c}16.7 \\
(+8 \%)\end{array}$ & $\begin{array}{c}14.3 \\
(-8 \%)\end{array}$ & $\begin{array}{c}14.9 \\
(-4 \%)\end{array}$ & $\begin{array}{c}16.9 \\
(+9 \%)\end{array}$ \\
Stationary fuels & 25.4 & $\begin{array}{c}23.6 \\
(-7 \%)\end{array}$ & $\begin{array}{c}18.5 \\
(-27 \%)\end{array}$ & $\begin{array}{c}17.9 \\
(-30 \%)\end{array}$ & $\begin{array}{c}15.9 \\
(-38 \%)\end{array}$ \\
Total & 40.9 & $\begin{array}{c}40.3 \\
(-1 \%)\end{array}$ & $\begin{array}{c}32.8 \\
(-20 \%)\end{array}$ & $\begin{array}{c}32.8 \\
(-20 \%)\end{array}$ & $\begin{array}{c}32.8 \\
(-20 \%)\end{array}$ \\
\hline
\end{tabular}

The column headed 1990 reports emission levels in 1990 and column 2005 reports benchmark emission levels.

Source: Federal Office for the Environment (2011) and own computations.under a Lump-Sum Recycling Scheme

Table 2 reports $\mathrm{CO}_{2}$ emissions from the combustion of stationary fuels, transportation fuels, and total emissions in million tons of $\mathrm{CO}_{2}$ and as percentage reductions compared to 1990 for the case of lump-sum revenue recycling. In all scenarios a larger fraction of emission reduction comes from reduced demand for stationary fuels. The tax exemption and the optimal tax, which do not alter the overall abatement target, shift the burden of emission reduction even more towards stationary fuels. While transport related emissions are reduced in the uniform and the optimal tax cases, transportation fuel use slightly increases when transportation fuels are exempted from the tax. 


\subsection{Carbon Tax Revenue and Redistribution}

Table 3 reports the revenue from the carbon tax in billion CHF. While the revenue in all uniform and optimal taxation scenarios lies between nine and ten billion CHF, the revenue is higher in the exempt cases.

Table 3: Carbon Tax Revenue in Billion CHF

\begin{tabular}{lccc}
\hline & Uniform & Optimal tax & Exempt \\
\hline lump-sum & 9.5 & 9.4 & 10.2 \\
vat & 10.0 & 9.9 & 10.5 \\
capital & 9.5 & 9.4 & 10.1 \\
labor & 9.9 & 9.9 & 11.0 \\
\hline
\end{tabular}

High revenues reflect high potential cut-backs in existing taxes and high lumpsum payments. As indicated by Table 4, the value-added tax can be reduced from $7.6 \%$ to $3.3 \%$ using the revenue of a uniform tax. ${ }^{15}$ The revenue generated by a tax on stationary fuels only can even make a reduction to $3.2 \%$ possible.

Table 4: Annual Per Capita Lump-Sum Rebate in CHF and Reduced Ad-Valorem Tax Rates in \%

\begin{tabular}{lcccc}
\hline & 2005 & Uniform & Optimal tax & Exempt \\
\hline lump-sum (CHF/capita) & - & 1280 & 1265 & 1374 \\
vat (tax rate in \%) & 7.6 & 3.3 & 3.4 & 3.2 \\
capital (tax rate in \%) & 23.8 & 16.8 & 17.0 & 16.5 \\
labor (tax rate in \%) & 23.3 & 18.6 & 18.6 & 18.3 \\
\hline
\end{tabular}

Direct taxes on capital or labor can be reduced significantly as well. As the federal income taxes are already low, it is possible to abandon direct taxes almost completely. If state and communal taxes are taken into account as well, average

$157.6 \%$ is the value-added tax rate for "normal" goods and services. Special rates e.g. for food and the hotel sector are reduced proportionally. 
capital and labor tax rates can be reduced from 23.8 to $16.5 \%$ for capital or from 23.3 to $18.3 \%$ for labor taxes. In the case of lump-sum revenue recycling, the annual lump-sum payments range between 1265 and $1374 \mathrm{CHF}$ per capita.

\subsection{Welfare Costs of Exemptions and the Double Dividend}

Table 5 reports Hicksian equivalent variations as a measure of the welfare effects resulting from different policies. To report societal equivalent variations I use a social welfare function that takes the form:

$$
S W F=\left(\sum_{h} n_{b} u_{b}^{\rho}\right)^{\frac{1}{\rho}}
$$

Where $u_{b}$ is the average equivalent per capita utility of a type household, $n_{b}$ is the share of type h household members in the total population, and $\rho$ is the inequality aversion parameter. If $\rho=1$ there is no inequality aversion and the societal equivalent variation is a weighted sum of equivalent variations over all households. This utilitarian social welfare function is referred to as Benthams social welfare function. As $\rho$ declines, inequality becomes more important, and in the limit $\rho \rightarrow-\infty$ the SWF becomes $\min _{h} u_{h}$ and thus, only the utility of the poorest household enters social welfare. This is called Rawls' social welfare function. When $\rho=0$, both cost-effectiveness and equality enter social welfare considerations. In this case - in the limit $\rho \rightarrow 0-$ the function is $\Pi_{u} u_{b}^{n_{b}}$. The function in this case is called Nash's social welfare function.

Social welfare decreases for all tax reforms when applying Benthams social welfare function. It should be noted, however, that this is a cost-side exercise. Benefits of the environmental policies, like increased air quality or less congestion, are not taken into account. There is no evidence for a strong double dividend. As Bovenberg and De Mooij (1994) and Bovenberg and Goulder (1996) have shown, the presence of an environmental tax decreases real return to factors and, thus, factor supply. Carbon abatement comes at a cost, which cannot be compensated for by reducing pre-existing taxes.

The excess burden of a proposal increases as the tax base decreases. Full exemption of transportation fuels raises total cost of emission abatement between $25 \%$ and $300 \%$ compared to uniform tax rates, depending on the mode of revenue recycling. Tax exemptions for transportation fuels, responsible for about $40 \%$ of benchmark emissions, cause fuel consumption for private transportation to decline less and shift the burden of emission reduction to other fuels. As 
Table 5: Hicksian Equivalent Variation (\% of Benchmark Consumption)

\begin{tabular}{llll}
\hline & Uniform & Optimal tax & Exempt \\
\hline & \multicolumn{2}{c}{ Bentham: $\rho=1$} & \\
lump-sum & -0.28 & -0.26 & -0.35 \\
vat & -0.04 & -0.04 & -0.13 \\
capital & -0.25 & -0.23 & -0.31 \\
labor & -0.14 & -0.13 & -0.21 \\
\hline & Nash: $\rho=0$ & & \\
& -0.01 & 0.05 & 0.02 \\
lump-sum & -0.11 & -0.06 & -0.05 \\
vat & -0.56 & -0.49 & -0.55 \\
capital & 0.05 & 0.07 & 0.04 \\
labor & Rawls: $\rho=-\infty$ & \\
\hline & 3.07 & 3.00 & 3.40 \\
lump-sum & -0.77 & -0.75 & -0.79 \\
vat & -1.44 & -1.41 & -1.37 \\
capital & -3.11 & -3.05 & -3.20 \\
labor & & & \\
\hline
\end{tabular}

a consequence, higher marginal tax rates and induced welfare losses are required to achieve a given economy-wide target of emission reduction. The "optimal tax" scenarios are superior to the "uniform" tax scenarios for most social welfare functions. ${ }^{16}$ Since a share of the pre-existing fuel tax is assumed not to internalize any external effect other than global warming, utility will decrease less with fuel-specific tax rates that equal out the pre-existing fuel tax.

Comparing different rebatement schemes, I find that if the revenue is used to reduce value-added taxes, utilitarian (Bentham) welfare losses are minimized. Although Swiss value-added tax rates are rather small compared to direct taxes on labor and capital, they affect the economy in the same way. On the one hand the value-added tax is charged on labor and capital as well. As such reducing value-added taxes decreases the same distortions as would reduced labor and capital taxes. But the excess burden of taxation on labor and capital falls simultaneously. Since the excess burden of a tax increases with the tax rate, reducing a

16 They are superior as long as the inequality parameter is not too important, meaning they are not Pareto-superior. 
single tax rate is not the most efficient course of action. Thus a value-added tax reduction is the more cost-effective scheme. In my analysis a labor tax reduction is superior to a capital tax reduction. The main drivers behind this result are two assumptions. First, economy-wide capital supply is assumed to be inelastic, and, second, impacts on growth are not considered. Both assumptions make capital tax reductions look less favorable. Clearly, lump-sum recycling is the worst from an efficiency point of view, since lump-sum taxes do not introduce distortions, a lump-sum transfer does not reduce distortions of any sort either.

The Rawlsian equivalent variations equal the equivalent variations of the poorest household. ${ }^{17}$ Given a Rawlsian social welfare function a social planner would prefer a lump-sum rebate. The poorer the household, the larger is the percentage increase in disposable income. As the poorest household is a retired one, a reduction of labor taxes would be the least effective policy. ${ }^{18}$ If the tax revenue is redistributed, income effects dominate consumption patterns for evaluating distributional concerns, and carbon taxes, although regressive themselves, do not necessarily have a regressive influence if the tax reform is revenue-neutral.

The equivalent variations for a Nash society often lie in between the results of the other functions. It is noteworthy that under this social regime labor tax reductions can be the preferable policy.

\subsection{Welfare Distribution}

Figures 2 and 3 report equivalent variations of all household groups. As discussed in the previous section a value-added tax reduction is the utilitarian cost-effective policy. However, in terms of the distributional outcome, all tax reforms are generally regressive but for a lump-sum recycling scheme. While a reduction in the regressive value-added tax results in an only slightly regressive reform, reductions in progressive taxes, as the labor tax, and to a larger extent, the capital tax, make the reform clearly regressive. However, lump-sum recycling leads to a progressive tax reform, where the poorest employed households and poorer retired households would be even better off. But this equity-improving reform comes at a cost: Regarding the Bentham societal equivalent variation, value-added tax reductions would be less costly.

$17 \mathrm{RH} 1$ is the poorest household in all simulations. Using the Rawlsian social welfare function, a modeler has to check whether the income ranking of the household groups changes.

18 Of course, this does not hold if one takes the poorest employed household as a reference. This household would prefer a reduction in labor instead of capital taxes. 
Figure 2 shows the Hicksian equivalent variations graphically for all employed households. As the graphs indicate, partial and full exemptions do not change the distributional outcomes qualitatively but impact efficiency in general. Full exemption is Pareto-dominated by uniform and optimal tax rates, ${ }^{19}$ while a partial exemption, as in the "Optimal tax" case, is very close to the outcome of a uniform tax.

Figure 3 demonstrates that the same distributional consequences of the different tax reforms arise for retired households. As the environmental tax base changes, the welfare of the household groups change in their absolute values but not relatively to each other. Thus fuel-specific tax exemptions do not alter distributional outcomes but are important for cost-effectiveness.

\subsection{Income Decomposition}

The analysis of the different sources of income sheds light on the role of revenue recycling and relative price changes. Households receive their income from supplying labor and capital and earning transfers. To make the impacts on the income side of the households visible, the Hicksian-equivalent variations are decomposed into shares of income components. Figure 4 shows the decomposition of the effect of the optimal $\mathrm{CO}_{2}$ tax on the income of employed households.

The results for the equivalent variations (EV) are the same as those previously plotted, but the impact of capital (K) and labor (L) income and net taxes and transfers (trn) are added, which sum up to the relative EV impact. If the revenue of an optimal carbon tax is redistributed lump-sum (Figure 4a), the main impact on households' welfare stems from transfers from the government, caused by the lump-sum tax recycling. Income from labor and capital are decreased compared to 2005 , since the tax affects the return on factors negatively. The lump-sum transfer more than compensates the poorer $20 \%$ of the households for this effect, making the overall tax reform progressive.

If the revenue is used to reduce taxes on factors, as in the labor and capital tax reduction counterfactuals (Figures $4 \mathrm{c}$ and $4 \mathrm{~d}$ ), the factor income of the respective factor increases. This effect benefits the households that supply relatively more of this factor. As a result, the winners of a capital tax reform are very rich employed or retired households, while a discount on labor taxes especially benefits

19 The only exemption to this is the lump-sum rebate case, where the increase in revenue from the decreased tax base of an exemption of transportation fuels, allows for high lump-sum payments and is therefore preferred by the poorest households. 


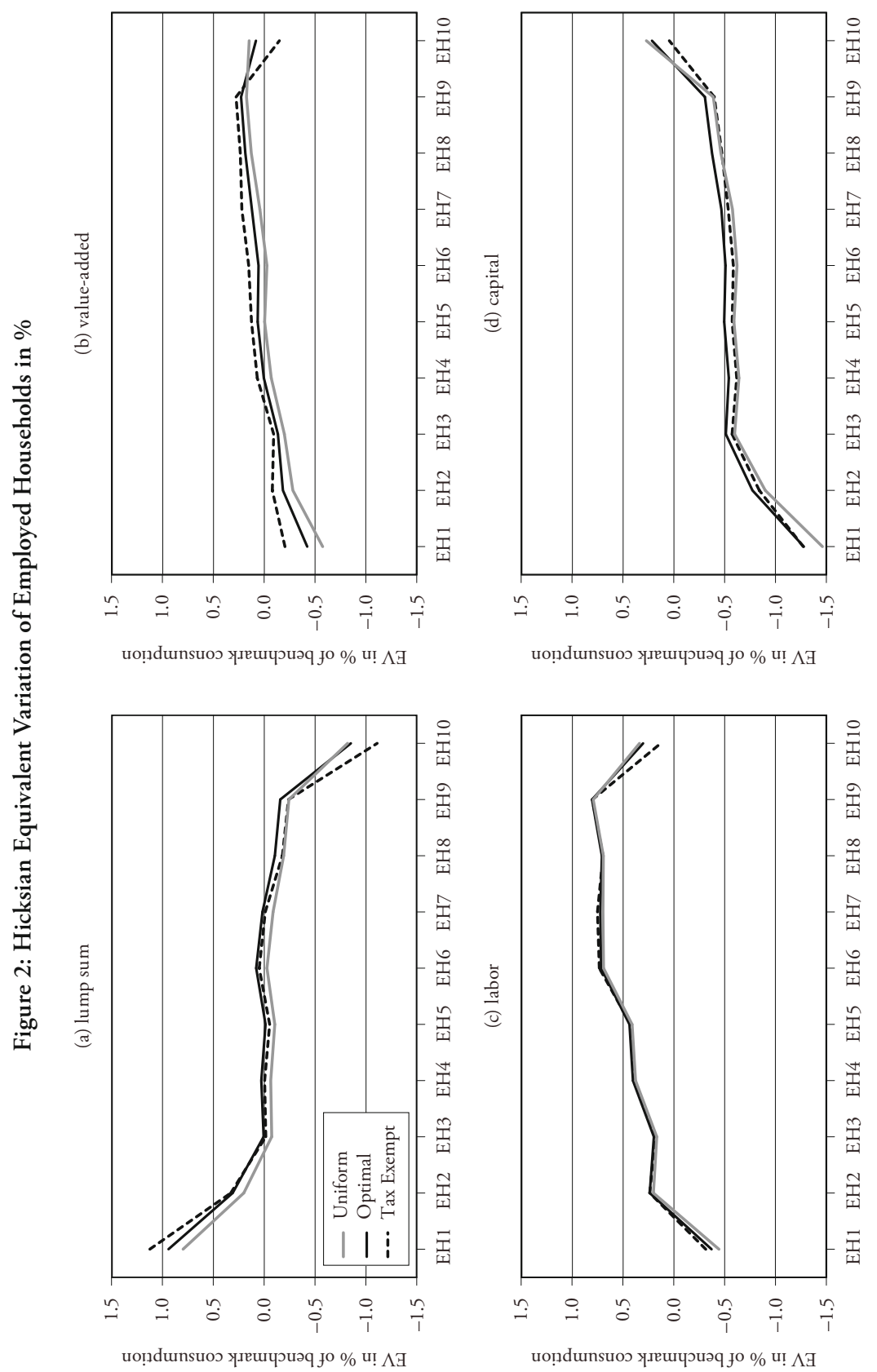




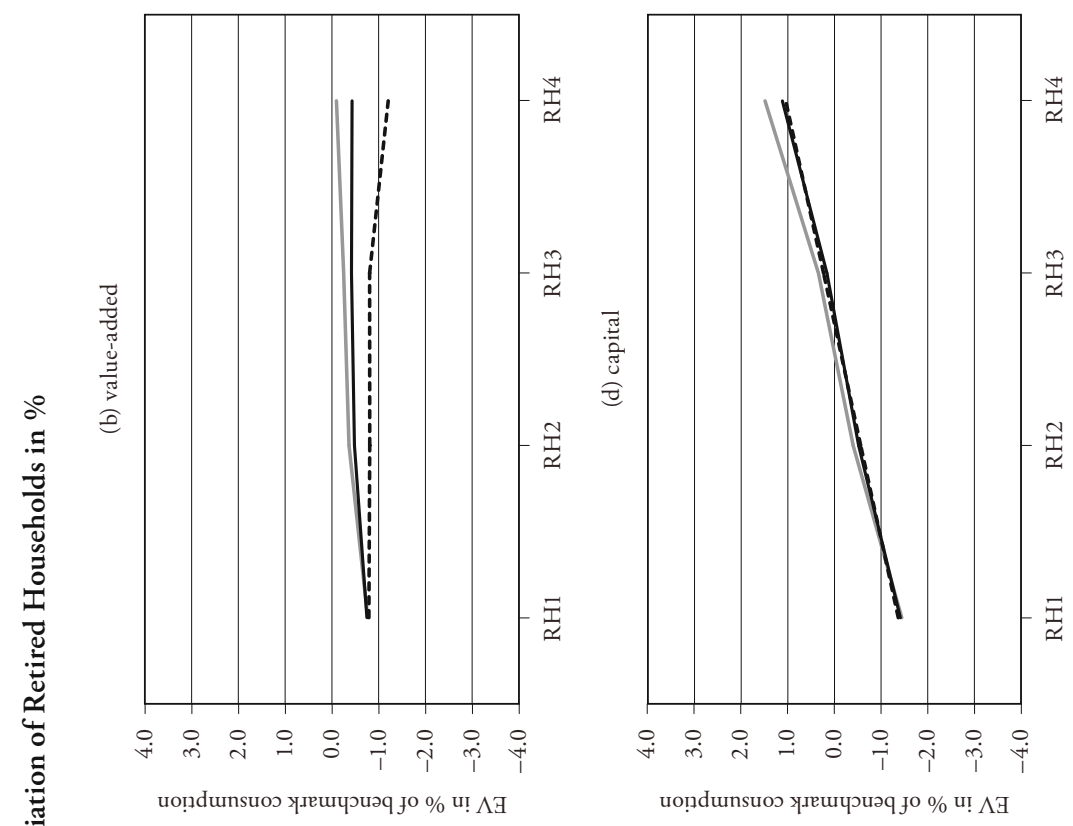

$\underset{\sim}{\stackrel{4}{2}}$

$\underline{\pi}$

$\underline{1}$

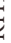

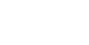

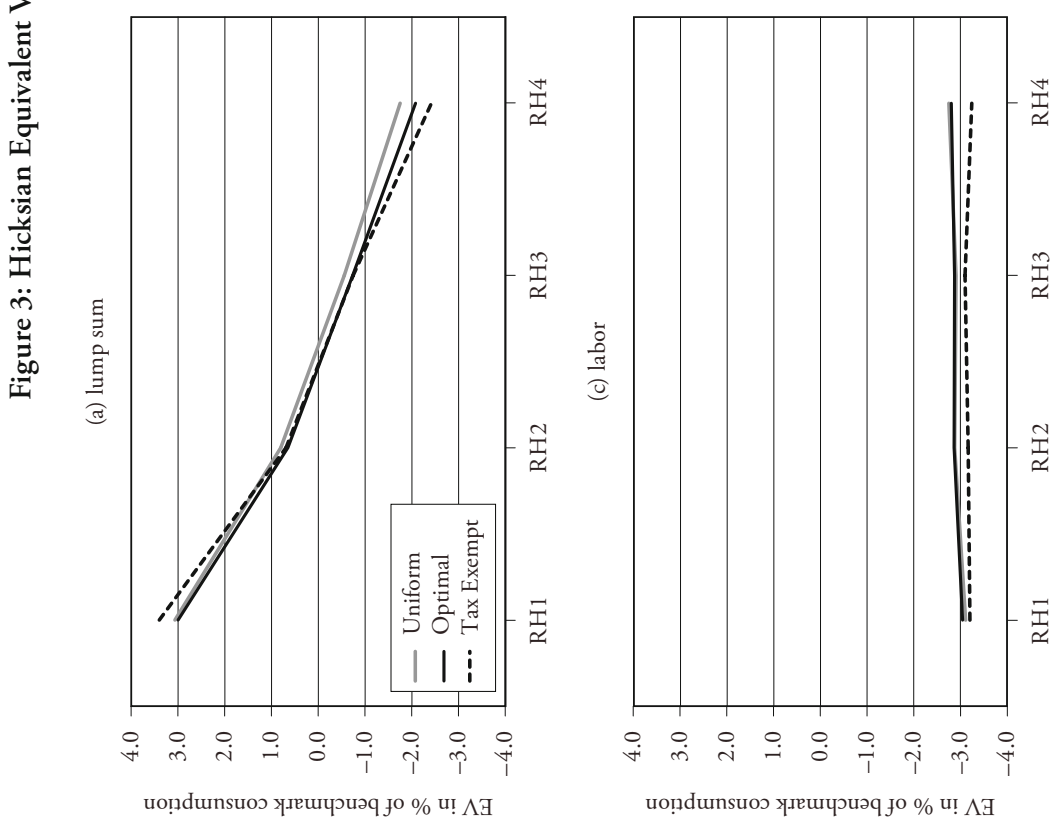

Swiss Journal of Economics and Statistics, 2012, Vol. 148 (2) 

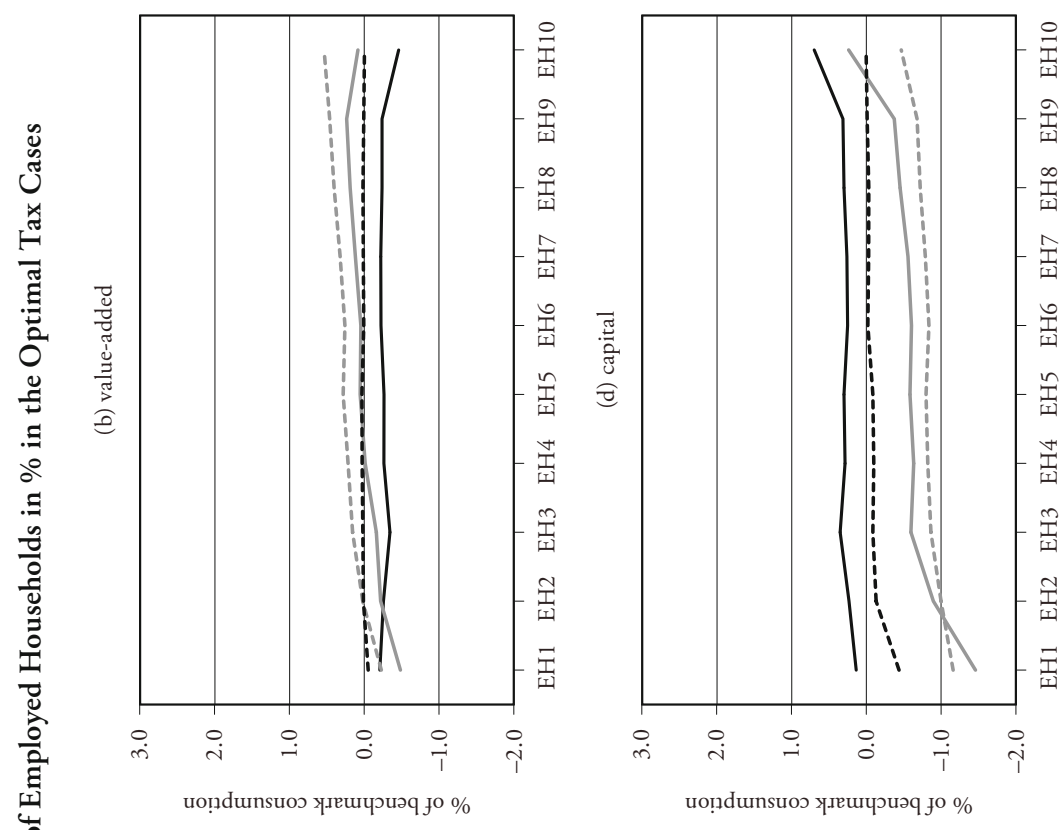

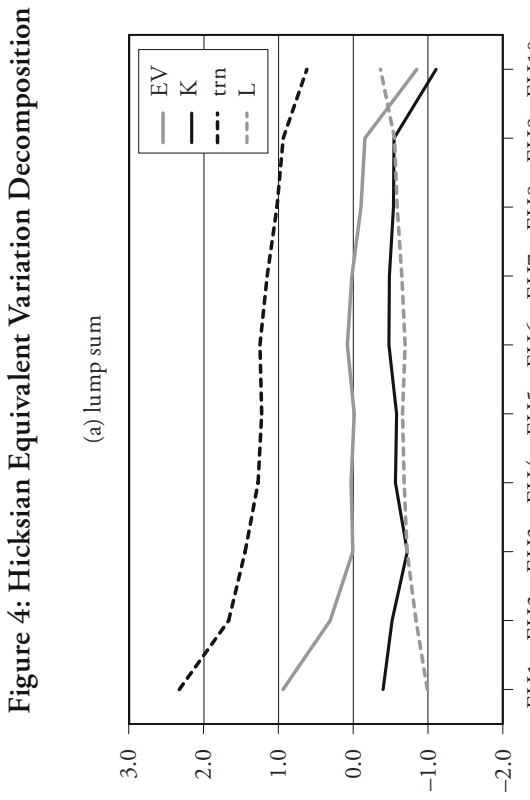

uọ̣dunsuoว угешцวиәq јо \%

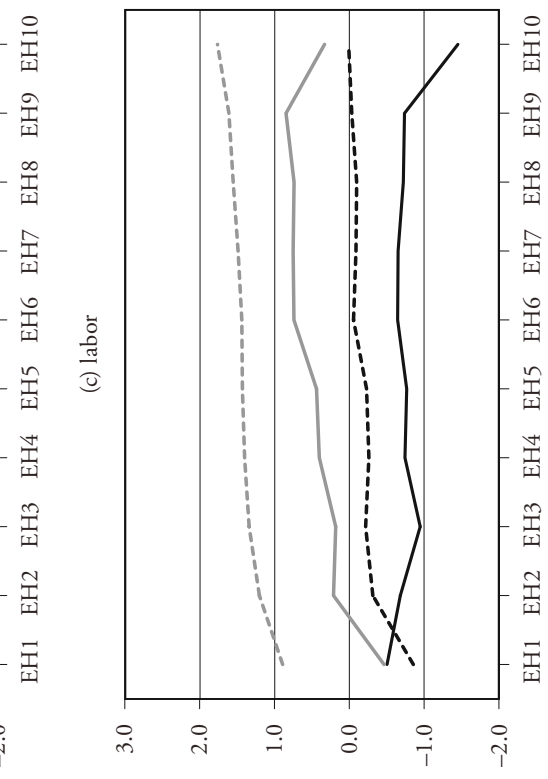

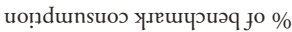


rich employed households and harms retired households. ${ }^{20}$ Finally, a value-added tax reduction reduces the tax burden on both, labor and capital, and, therefore, causes an intermediate outcome (Figure $4 \mathrm{~b}$ ).

\section{Sensitivity Analysis}

I carried out a number of counterfactual simulations changing various parameter values. I checked the results of the additional counterfactuals regarding marginal cost of abatement, tax revenue, efficiency, and distributional consequences of the tax regimes under study. The sensitivity analysis shows that the model's results are quite robust with respect to most parameter values. More influential parameters are the elasticity of substitution on the top nest of the production function $\left(\sigma_{s}\right)$, the elasticity of substitution between electricity and fossil fuels $\left(\sigma_{e}\right)$, the elasticity of substitution between transportation fuels and other inputs in the transport sector $\left(\sigma_{t}\right)$, and the labor endowment of the households. While their impact on efficiency can be huge quantitatively, they do not alter qualitative results. The ranking of the scenarios with respect to welfare remains unchanged. Distributional results are only changed quantitatively as well. The same households still prefer the same proposals.

While changing the time endowment of the households has only a minor effect on the marginal abatement cost, revenue and thus tax reductions, the energy related elasticities do have strong effects on marginal cost estimates.

Table 6 reports necessary tax rates for different rebatement schemes and optimal tax rates for the piecemeal sensitivity analysis of key elasticities of substitution in the production functions. All parameters affect the model in the same way. When elasticities are increased associated tax rates and welfare losses decrease. Optimal tax rates are quite sensitive to the reported parameters, but qualitative results remain unaffected.

Table 7 reports the results of the labor supply parameters. $\sigma_{l}$ is the elasticity of substitution between leisure and aggregate consumption. $E_{L}$ is the time endowment of the households in excess to what has been supplied in 2005. If $e_{L}$ is equal to 2 the household consumes double the amount of time as leisure as he sells to firms as work time.

More elastic labor supply works exactly in the opposite direction as increased elasticities of substitution in the production functions do. It decreases the cost of

20 Figures for the retired household groups can be found in Appendix B. 
Table 6: Piecemeal Sensitivity Analysis of Key Elasticities

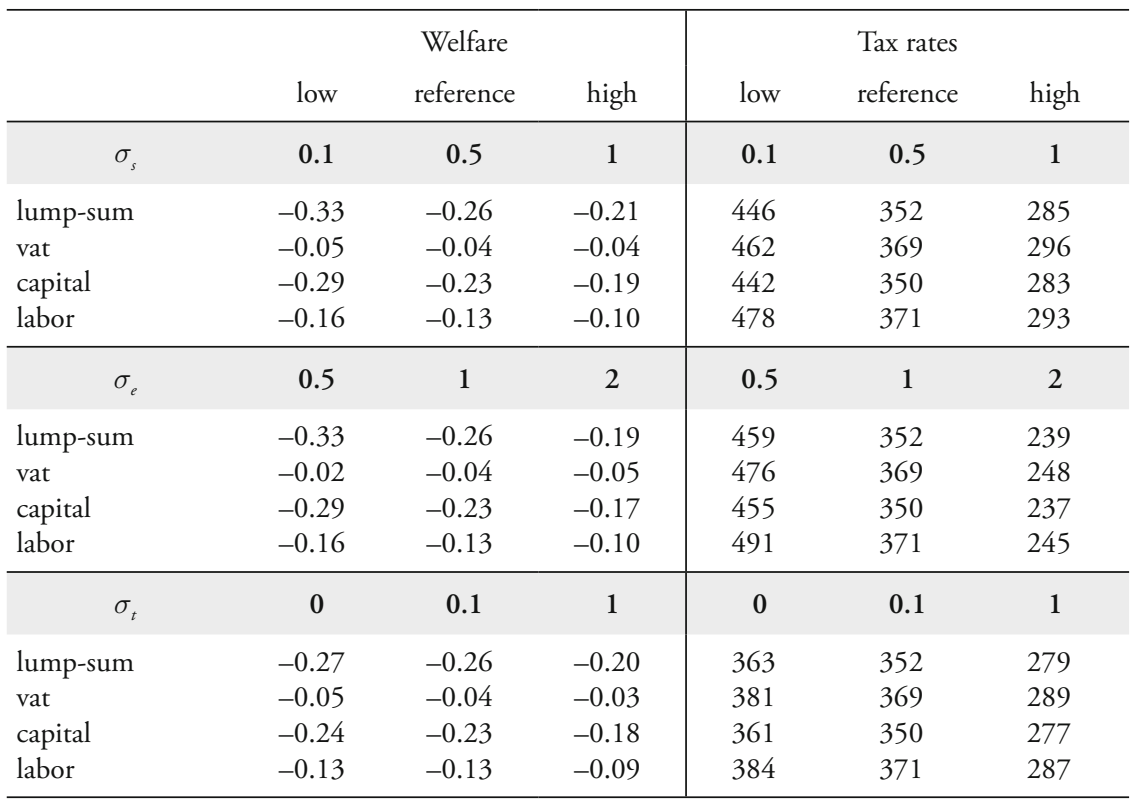

The Table shows Hicksian equivalent variations measured in $\%$ of the value of 2005 consumption for a Bentham social welfare function and tax rates on stationary fuels measured in $\mathrm{CHF} / \mathrm{tCO}$ for counterfactuals with optimal tax rates.

carbon abatement. If the environmental tax revenue is used to reduce labor tax rates, labor supply increases more when labor supply is highly elastic, propelling economic activity and making higher tax rates necessary. This is different to the effect of other elasticities or with other rebatement schemes.

\section{Conclusion}

I use a static computable general equilibrium model of the Swiss economy (CEPE) to examine the consequences of 12 different green tax proposals on efficiency and equity. The carbon tax is either levied uniformly on all fossil fuels ("Uniform"), on stationary fuels only ("Exempt"), or less on transportation fuels than stationary fuels ("Optimal tax") such that the reduced carbon tax rate on transportation fuels accounts for the distorting share of the pre-existing petroleum tax. In 
Table 7: Piecemeal Sensitivity Analysis of Labor Supply

\begin{tabular}{|c|c|c|c|c|c|c|c|c|c|}
\hline & \multicolumn{3}{|c|}{0.1} & \multicolumn{3}{|c|}{0.65} & \multicolumn{3}{|c|}{1} \\
\hline & 0 & 1 & 2 & 0 & 1 & 2 & 0 & 1 & 2 \\
\hline$\sigma_{l}$ & \multicolumn{9}{|c|}{$\mathrm{CO}_{2}$ tax rates on stationary fuels in $\mathrm{CHF} / \mathrm{CCO}_{2}$} \\
\hline lump-sum & 360 & 361 & 362 & 360 & 352 & 350 & 360 & 348 & 345 \\
\hline vat & 367 & 368 & 368 & 367 & 369 & 370 & 367 & 370 & 376 \\
\hline capital & 352 & 359 & 361 & 352 & 350 & 349 & 352 & 346 & 344 \\
\hline wage & 360 & 357 & 357 & 360 & 371 & 375 & 360 & 380 & 389 \\
\hline$e_{L}$ & \multicolumn{9}{|c|}{ Hicksian equivalent variation measured in $\%$ of 2005 consumption } \\
\hline lump-sum & -0.31 & -0.20 & -0.14 & -0.31 & -0.26 & -0.21 & -0.31 & -0.30 & -0.24 \\
\hline vat & -0.11 & -0.06 & -0.04 & -0.11 & -0.04 & -0.03 & -0.11 & -0.03 & 0.00 \\
\hline capital & -0.32 & -0.17 & -0.11 & -0.32 & -0.23 & -0.18 & -0.32 & -0.27 & -0.22 \\
\hline wage & -0.31 & -0.22 & -0.16 & -0.31 & -0.13 & -0.07 & -0.31 & -0.06 & -0.01 \\
\hline
\end{tabular}

The Table shows tax rates for stationary fuels and Hicksian equivalent variations measured in $\%$ of the value of benchmark consumption for a Bentham social welfare function for counterfactuals with "optimal tax" rates.

either case I choose the tax rates such that the total emission reduction is $20 \%$ compared to 1990 levels. I compute equilibria for these three tax regimes using the tax revenue for four different purposes, such that the tax reform is revenueneutral. The revenue of the tax is redistributed as a per capita lump-sum transfer or through a reduction in value-added, labor, or capital taxes.

I examine how these tax reforms impact on 14 household groups and three social welfare functions. The three social welfare functions differ in their inequality parameters from being utilitarian (Bentham), Rawlsian or moderate (Nash). I can confirm the findings of Metcalf (2007) and Graigner and Kolstad (2009) and show that revenue recycling is the crucial policy parameter when it comes to distributional concerns. I find that equity, however, is not much affected by exemptions. Even though consumption patterns differ from household to household as argued by ScOTT and Eakins (2004), impacts on households' welfare are dominated by income effects. Therefore, the tax rates should be chosen solely regarding cost-effectiveness.

I find that tax exemptions for certain fuels are costly as they prevent equalization of marginal abatement costs and thus prevent an efficient allocation of abatement activities as has been found by BöHRINGER and RUTHERFORD (1997). However, a tax discount on transportation fuels is optimal, if I assume that a part 
of the pre-existing petroleum tax does not internalize any external effects. While PAltsev et al. (2005) argue that either uniform taxes or exemptions may be optimal depending on the pre-existence of fuel taxes, I show that a tax exemption is not an either/or question: the optimal tax rates have to be adjusted for pre-existing petroleum taxes. However, the share of the pre-existing tax to be deducted from the $\mathrm{CO}_{2}$ tax depends on which share of the tax is believed to be justified by other external effects. I make the assumption that about one third of the preexisting tax is not internalizing any externality. I choose this share in accordance to the share of the tax that enters the general federal budget. This assumption is arbitrary and crude but serves as an upper bound for the optimal $\mathrm{CO}_{2}$ tax discount on transportation fuels. To address this concern more accurately, further research could lead to models that portray the public goods and other welfare benefits that are explicitly internalized by those fuel taxes.

While I focus on the distributional effects of carbon taxes on different income groups, it would be interesting for further research to investigate the effects on different geographical regions. The Swiss income and expenditure survey offers the opportunity to do so. However, a regional Swiss CGE model would be necessary for such a task and this has not been done so far since necessary regional data is not available.

I conclude that in terms of cost-effectiveness, the Swiss authorities should prefer uniform carbon taxes such that the tax rates should be corrected for the share of the petroleum tax added to the general federal budget. If the revenue is then used for a reduction of value-added taxes the tax reform would be cost-effective. If distributional equity is considered as well, per-capita lump-sum rebatement leads to a progressive tax reform at a moderate cost. 


\section{Appendix}

\section{Equity}

Table 8: Household Expenditures on Energy

\begin{tabular}{|c|c|c|c|c|}
\hline & $\begin{array}{c}\text { Total } \\
\text { Consumption }\end{array}$ & $\begin{array}{l}\text { Fossil } \\
\text { Fuels }\end{array}$ & $\begin{array}{c}\text { Transportation } \\
\text { Fuels }\end{array}$ & $\begin{array}{l}\text { Stationary } \\
\text { Fuels }\end{array}$ \\
\hline & CHF per month & \multicolumn{3}{|c|}{$\%$ of Consumption } \\
\hline Average Household & 4853 & 3.6 & 3.0 & 0.6 \\
\hline \multicolumn{5}{|c|}{ Greater Regions } \\
\hline Lake Geneva & 4797 & 4.4 & 3.5 & 0.9 \\
\hline Espace Mittelland & 4663 & 3.8 & 3.1 & 0.7 \\
\hline Northwest & 5213 & 3.0 & 2.4 & 0.6 \\
\hline Zurich & 5260 & 2.6 & 2.1 & 0.5 \\
\hline East & 4430 & 3.8 & 3.2 & 0.6 \\
\hline Central & 4873 & 3.0 & 2.8 & 0.2 \\
\hline Ticino & 4363 & 5.7 & 4.3 & 1.5 \\
\hline \multicolumn{5}{|c|}{ Working: Income Deciles of Working Households } \\
\hline EH1 ( $1^{\text {st }}$ income decile $)$ & 2868 & 5.8 & 4.2 & 1.5 \\
\hline $\mathrm{EH} 2$ & 3781 & 4.8 & 3.4 & 1.4 \\
\hline $\mathrm{EH} 3$ & 4184 & 4.5 & 3.1 & 1.4 \\
\hline EH4 & 4865 & 3.9 & 2.7 & 1.2 \\
\hline $\mathrm{EH} 5$ & 4977 & 3.8 & 2.6 & 1.2 \\
\hline EH6 & 5029 & 3.8 & 2.6 & 1.2 \\
\hline $\mathrm{EH} 7$ & 5397 & 3.6 & 2.5 & 1.2 \\
\hline EH8 & 6025 & 3.3 & 2.2 & 1.1 \\
\hline EH9 & 6529 & 3.1 & 2.0 & 1.1 \\
\hline $\mathrm{EH} 10\left(10^{\text {th }}\right.$ income decile $)$ & 8830 & 2.7 & 1.5 & 1.1 \\
\hline \multicolumn{5}{|c|}{ Retired: Income Quartiles of Retired Households } \\
\hline RH1 (1t income quartile) & 1781 & 5.8 & 4.4 & 1.4 \\
\hline RH2 & 2634 & 4.7 & 3.5 & 1.3 \\
\hline RH3 & 3533 & 4.3 & 3.2 & 1.1 \\
\hline RH4 (4 $4^{\text {th }}$ income quartile) & 5946 & 3.0 & 2.0 & 1.0 \\
\hline
\end{tabular}

Source: EVE 2001 and Ecoplan.

A carbon tax changes the relative prices of goods and thus impacts consumers differently. A household spending relatively more of its income on carbon-intensive goods will bear more of the burden. If certain households spend a smaller 
relative share of their income on transportation fuels, while their expenditures on stationary fuels are disproportionally large, they may be negatively affected by an exemption for transportation fuels. For Switzerland, the Statistical Office (SFSO) has gathered expenditure and income data of Swiss households since 1912. Based on the income and expenditure survey (EVE) from 2001 Table 9 illustrates that the biggest difference in the relative consumption of fuels results from differences in income.

While expenditure shares for fossil fuels by greater region range from $2.6 \%$ for the Zurich area to $5.7 \%$ for Ticino, the expenditure shares, if classified by differences in income, range from $5.8 \%$ for poor households to $2.7 \%$ for the richest working households. Regional characteristics of households are important. In rural areas, where less public transport is available, the consumption of fossil fuels is larger than in urban areas. Ideally I would employ a multidimensional household grouping. Unfortunately, the EVE consists of only 3000 observations per year and, thus, a multidimensional classification would be statistically weak. I therefore restrict myself to the examination of distributional effects on income groups and leave the geographical issue to further research. 


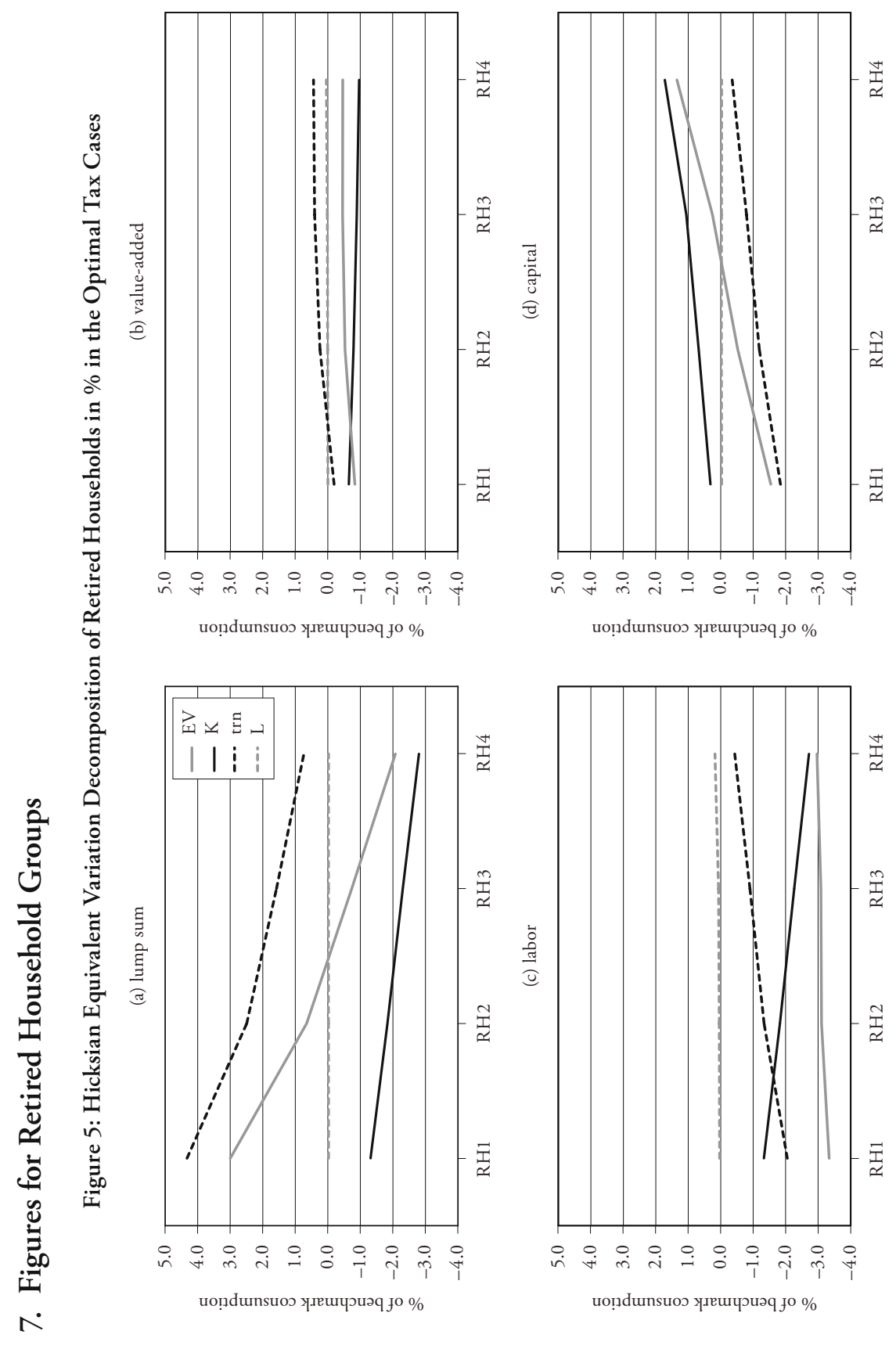

Swiss Journal of Economics and Statistics, 2012, Vol. 148 (2) 


\section{Sectoral Impacts}

Figure 6 shows some aspects of the sectoral impacts of the "Optimal tax" case with lump-sum recycling. Figure 6a shows the 10 largest $\mathrm{CO}_{2}$ emitting sectors and their respective $\mathrm{CO}_{2}$ emissions measured in million tons. Figure $6 \mathrm{~b}$ shows the change in real production in percent of 2005 production for the 5 most growing and the five most declining sectors under the policy proposal. Figures $6 \mathrm{c}$ and $6 \mathrm{~d}$ show $\mathrm{CO}_{2}$ reductions for the 10 sectors with the largest absolute and relative reductions, respectively.

Sectoral impacts do not change much in different tax scenarios. If transportation fuels are taxed more, the transport sector, and sectors that use a lot of transportation, are affected more. 

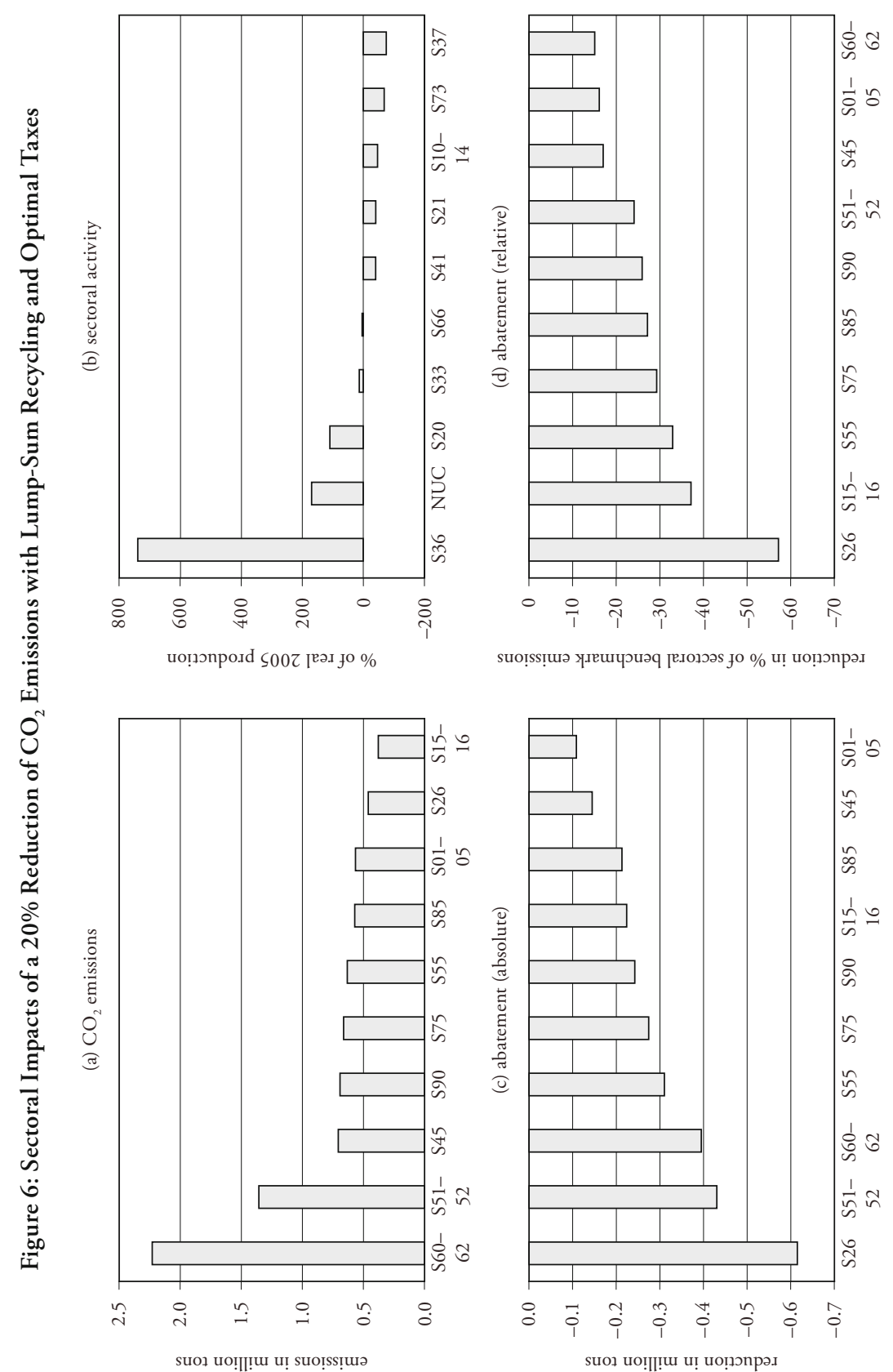

Swiss Journal of Economics and Statistics, 2012, Vol. 148 (2) 


\section{Sectors}

\section{Table 9: Sectors in the Model}

\section{Standard NOGA Sectors in 2001 IOT}

\begin{tabular}{|c|c|}
\hline S01-S05 & $\begin{array}{l}\text { Agriculture, hunting and related service activities; Forestry, logging and related } \\
\text { service activities; Fishing, fish farming and related service activities }\end{array}$ \\
\hline S10-S14 & Mining and quarrying (includes also NOGA 10-13) \\
\hline S15-S16 & Manufacture of food products and beverages; Manufacture of tobacco products \\
\hline S17 & Manufacture of textile \\
\hline S18 & Manufacture of wearing apparel; dressing and dyeing of fur \\
\hline S19 & $\begin{array}{l}\text { Tanning and dressing of leather; manufacture of luggage, handbags, saddlery, } \\
\text { harness and footwear }\end{array}$ \\
\hline S20 & $\begin{array}{l}\text { Manufacture of wood and of products of wood and cork, except furniture; } \\
\text { manufacture of articles of straw and plaiting materials }\end{array}$ \\
\hline S21 & Manufacture of pulp, paper and paper products \\
\hline S22 & Publishing, printing and reproduction of recorded media \\
\hline S25 & Manufacture of rubber and plastic products \\
\hline S26 & Manufacture of other non-metallic mineral products \\
\hline S27 & Manufacture of basic metals \\
\hline S28 & Manufacture of fabricated metal products, except machinery and equipment \\
\hline S29 & Manufacture of machinery and equipment n.e.c. \\
\hline S30-S31 & $\begin{array}{l}\text { Manufacture of office machinery and computers; Manufacture of electrical } \\
\text { machinery and apparatus n.e.c. }\end{array}$ \\
\hline S32 & Manufacture of radio, television and communication equipment and apparatus \\
\hline S33 & Manufacture of medical, precision and optical instruments, watches and clocks \\
\hline S34 & Manufacture of motor vehicles, trailers and semi-trailers \\
\hline S35 & Manufacture of other transport equipment \\
\hline S36 & Manufacture of furniture; manufacturing n.e.c. \\
\hline S37 & Recycling \\
\hline S45 & Construction \\
\hline S50 & $\begin{array}{l}\text { Sale, maintenance and repair of motor vehicles and motorcycles; retail sale of } \\
\text { automotive fuel }\end{array}$ \\
\hline S51-S52 & $\begin{array}{l}\text { Wholesale trade and commission trade, except of motor vehicles and } \\
\text { motorcycles; Retail trade, except of motor vehicles and motorcycles; repair of } \\
\text { personal goods }\end{array}$ \\
\hline
\end{tabular}


Standard NOGA Sectors in 2001 IOT

\begin{tabular}{|c|c|}
\hline S55 & Hotels and restaurants \\
\hline S60-S62 & Land transport; transport via pipelines; Water transport; Air transport \\
\hline S63 & Supporting and auxiliary transport activities; activities of travel agencies \\
\hline S64 & Post and telecommunications \\
\hline S65 & $\begin{array}{l}\text { Financial intermediation, except insurance and pension funding (includes also } \\
\text { part of NOGA 67) }\end{array}$ \\
\hline S66 & $\begin{array}{l}\text { Insurance and pension funding, except compulsory social security (includes } \\
\text { also part of NOGA 67) }\end{array}$ \\
\hline$S 70+S 96 / 97$ & Real estate activities (incl. private households) \\
\hline $\mathrm{S} 71+\mathrm{S} 74$ & $\begin{array}{l}\text { Renting of machinery and equipment without operator and of personal and } \\
\text { household goods; Other business activities }\end{array}$ \\
\hline S72 & Computer and related activities \\
\hline S73 & Research and development \\
\hline S75 & Public administration and defence; compulsory social security \\
\hline S80 & Education \\
\hline S85 & Health and social work \\
\hline$S 90$ & Sewage and refuse disposal, sanitation and similar activities \\
\hline S91-S92 & $\begin{array}{l}\text { Activities of membership organizations n.e.c.; Recreational, cultural and } \\
\text { sporting activities }\end{array}$ \\
\hline S93-S95 & Other service activities; Activities of households as employers of domestic staff \\
\hline
\end{tabular}

ELEC Electricity production (namely Nuclear power, water power and other public power plants from S40)

S40-S41 Rest of S40-S41: Electricity, gas, steam and hot water supply; Collection, purification and distribution of water (Without Electricity)

OIL Oil refining from crude (taken from sector S23)

S23-S24 Rest of S23-S24: Manufacture of coke, refined petroleum products and nuclear fuel; Manufacture of chemicals and chemical products (Without refined petroleum products)

Source: NOGA classification as in the 2001 Swiss IOT and own computations. 


\section{References}

Abrell, Jan (2010), "Regulating co2 Emissions of Transportation in Europe: A CGE Analysis Using Market-Based Instruments", Transportation Research Part D: Transport and Environment, 15(4), pp. 235-239.

Atrinson, A. B., and J. E. Stiglitz (1976), "The Design of Tax Structure: Direct versus Indirect Taxation", Journal of Public Economics, 6(1-2), pp. 55-75.

Ballard, Charles L. (1999), "How Many Hours Are in a Simulated Day? The Effects of Time Endowment on the Results of Tax-Policy Simulation Models", Working Paper. East Lansing, Michigan: Department of Economics, Michigan State University.

BöHringer, C. (2002), Flexible Mechanisms for an Efficient Climate Policy, vol. 11 of ZEW Economic Studies, chap. Shaping Greenhouse Gas Abatement Strategies - Policy Issues and Quantitative Insights, pp. 19-30, Springer, Heidelberg.

Böhringer, Christoph, and T. F. Rutherford (1997), "Carbon Taxes with Exemptions in an Open Economy - A General Equilibrium Analysis of the German Tax Initiative", Journal of Environmental Economics and Management, 32, pp. 189-203.

Bovenberg, A. L., and R. A. De Mooij (1994), "Environmental Levies and Distortionary taxation", American Economic Review, 84, pp. 1085-1089.

Bovenberg, A. L., and L. H. Goulder (1996), "Optimal Environmental Taxation in the Presence of Other Taxes: General-Equilibrium Analyses", American Economic Review, 86, pp. 985-1000.

Boyce, J., M. D. Brenner and M. Riddle (2005), "A Chinese Sky Trust? Distributional Impacts of Carbon Charges and Revenue Recycling in China", Tech. rep., Political Economy Research Institute, University of Massachusetts, Amherst.

Corong, E. L. (2008), "Tariff Reductions, Carbon Emissions, and Poverty: An Economy-Wide Assessment of the Philippines", ASEAN Economic Bulletin, 25(1), pp. 20-31.

Federal Office for the Environment (2011), "Emissionen nach CO2-Gesetz und Kyotoprotokoll”, Bern.

Goulder, L. H. (1995), "Environmental Taxation and the 'Double Dividend': A Reader's Guide", International Tax and Public Finance, 2, pp. 157-184.

Grainger, Corbett A., and Charles D. Kolstad (2009), "Who Pays a Price on Carbon?”, Working Paper 15239, National Bureau of Economic Research, URL http://www.nber.org/papers/w15239. 
Iмноғ, JAN (2011), "Subsidies, Standards and Energy Efficiency", The Energy Journal, 0(Special Issue), URL http://ideas.repec.org/a/aen/journl/32sil-a08.html.

Jacobs, Bas (2011), "From Optimal Tax Theory to applied tax policy. Lessons from the Netherlands for Norway", in The Research Forum on Taxation 'Skatteforum' in Moss, Norway.

Jorgenson, D. W., D. T. Slesnick, and P. J. Wilcoxen (1992), "Carbon Taxes and Economic Welfare", Brookings Papers on Economic Activity. Microeconomics, 1992, pp.393-454.

Metcalf, G. (2007), "A Proposal for a U.S. Carbon Tax Swap: An Equitable Tax Reform to Address Global Climate Change", Tech. rep., The Hamilton Project, Brookings Institution, Washington D.C.

Metcalf, G. E. (1999), "A Distributional Analysis of an Environmental Tax Shift”, National Tax J, 52, pp. 655-681.

Müller, Andr, and Renger van Nieuw koop (2009), „Volkswirtschaftliche Auswirkungen der Schweizer Post-Kyoto-Politik“, Tech. rep., Ecoplan.

Nathani, C., and M. Wickart (2006), "Estimation of a Swiss Input-Output Table from Incomplete and Uncertain Data Sources", Unpublished Paper, ETH Zurich, Department of Environmental Sciences.

Nathani, C., M. Wickart, and R. van Nieuw koop (2008), "Revision der IOT 2001 und Schätzung einer IOT 2005 für die Schweiz", Tech. rep., Centre for Energy Policy and Economics (CEPE), ETH Zuerich, rueschlikon / Bern / Zürich.

OECD (1995), "Climate Change, Economic Instruments and Income Distribution", Tech. rep., Organisation for Economic Co-operation and Development, Paris.

Paltsev, Sergey, Henry D. Jacoby, John M. Reilly, Laurent Viguier, and Mustafa Babiker (2005), "Modeling the Transport Sector: The Role of Existing Fuel Taxes in Climate Policy", Tech. rep., MIT Joint Program on the Science and Policy of Global Change.

Poterba, J. M. (1991), “Is the Gasoline Tax Regressive?", Tax Policy and the Economy, 5.

Sceia, André, Philippe Thalmann, and Marc Vielle (2010), "Assessment of the Economic Impacts of the Revision of the Swiss CO2 Law with a Hybrid Model", Tech. rep., Research Group on the economics and management of the environment (REME) - EPFL.

Scott, S., and J. Eakins (2004), "Carbon Taxes: Which Households Gain or Lose?”, Envionmental Protection Agency, Ireland.

Van Heerden, J., R. Gerlagh, J. Blignaut, M. Horridge, S. Hess, R. Mabugu, and M. Mabugu (2006), "Searching for Triple Dividends in South 
Africa: Fighting CO2 Pollution and Poverty while Promoting Growth", The Energy Journal, 27, pp. 113-141.

Wier, Mette, Katja Birr-Pedersen, Henrik Klinge Jacobsen, and Jacob Klok (2005), "Are CO2 Taxes Regressive? Evidence from the Danish Experience”, Ecological Economics, 52(2), pp. 239-251, URL http://ideas.repec.org/a/ eee/ecolec/v52y2005i2p239-251.html.

Wissema, Wiepke, and Roв Dellink (2007), "Age Assessment of Interactions

between Climate Change Policy Instruments and Pre-Existing Taxes: The Case of ireland", International Journal of Global Environmental Issues.

Yusuf, A. A., and B. Resosudarmo (2007), "On the Distributional Effect of Carbon Tax in Developing Countries: The Case of Indonesia", Working Paper in Economics and Development Studies 200705.

\section{SUMMARY}

The Swiss $\mathrm{CO}_{2}$ law runs out in 2012, together with the first commitment period of the Kyoto Protocol. Currently, the Swiss parliament is deciding on the successor of the law that aims to achieve a $20 \%$ reduction of $\mathrm{CO}_{2}$ emissions below 1990 levels by 2020. As a means to achieve this ambitious target, the current tax on stationary fuels at $36 \mathrm{CHF} / \mathrm{CO}_{2}$ will be maintained, while transportation fuels will still be exempted from the carbon tax. Currently, the tax revenues are fully redistributed as a per-capita lump-sum payment via mandatory health insurance and to the employers proportional to their wage payments. This recycling scheme is likely to be prolonged. However, in the presence of the actual debate on the revision of the $\mathrm{CO}_{2}$ law, this paper reexamines the exemption of transportation fuels and the revenue recycling scheme under two points of view. First, I examine the effects on cost-effectiveness and second, I study their impact on equity. Using a static computable general equilibrium model of the Swiss economy incorporating 14 household groups, I find that tax exemptions increase the economy-wide costs of a carbon tax, yet fail to ease the effect on over-proportionally affected households. However, adjusting $\mathrm{CO}_{2}$ tax rates to correct for pre-existing fuel taxes that do not internalize any external effects may decrease the economy-wide cost of a green tax reform. On the other hand the choice of the recycling scheme has less of an effect on efficiency, but its impact on the distributional outcome of the tax reform has to be considered. Choosing an optimal, economy-wide tax will decrease overall costs considerably, while a lump-sum per-capita rebate will result in a progressive tax package at reasonable costs. 